\title{
APPLICATION OF SULFONATED POLYSTYRENE IN POLYMER ELECTROLYTE FUEL CELL
}

\author{
Sunit Hendrana', Erwin ${ }^{2}$, Krisman $^{2}$, Syakbaniah $^{2}$, Isna'im $^{2}$, \\ Yusmeri $^{2}$, Neti Satria ${ }^{2}$, Tri Susilawati ${ }^{2}$ and Sudirman ${ }^{3}$ \\ ${ }^{1}$ Research Centre for Physics-Indonesian Institute of Sciences, \\ Kawasan Puspiptek, Gedung 440-442, Tangerang Selatan, Banten - 15314, Indonesia \\ ${ }^{2}$ Department of Physics, Faculty of Mathematics and Natural Sciences, Universitas Riau \\ ${ }^{3}$ Centre for Science and Technology of Advanced Materials - National Nuclear Energi Agency, \\ Kawasan Puspiptek, Gedung 71, Tangerang Selatan, Banten - 15314, Indonesia \\ E-mail: sunit.hendrana@lipi.go.id
}

Received: 2 August $2018 \quad$ Revised: 7 September $2018 \quad$ Accepted: 21 September 2018

\begin{abstract}
APPLICATION OF SULFONATED POLYSTYRENE IN POLYMER ELECTROLYTE FUEL CELL. Sulfonated polystyrene (SPS) is polyelectrolyte solid that widely used in many applications. In this works, SPS is applied as a membrane and membrane adhesives to make MEA (Membrane Electrode Assembly) for polymer electrolyte fuel cells due to the availability of sulfonate groups in their structure. The investigation involves the application as a membrane with the addition of small molecules, i.e. benzimidazole and evaluating its microstructure and performance. Application of SPS solution as a binding agent in MEA will also be presented. The results show when SPS is used as the fuel cell membrane, the addition of small molecules such as benzimidazole would modify the microstructure and improved the ion conductivity, as well as opening the opportunity for the higher temperature application. Meanwhile, some improvement still required for application of SPS solution as a binding agent for the preparation of MEA.
\end{abstract}

Keywords: Sulfonated polystyrene, Polymer electrolyte fuel cell, Microstructure, Benzimidazole, Ion conductivity

\begin{abstract}
ABSTRAK
APPLIKASI POLISTIRENA TERSULFONASI DALAM SEL BAHAN BAKAR POLIMER ELEKTROLIT. Polistirena tersulfonasi (SPS) adalah polielektrolit yang banyak digunakan dalam berbagai aplikasi. Dalam paper ini SPS diterapkan untuk membran dan perekat membran untuk membuat MEA (Membrane Electrode Assembly) dari sel bahan bakar polimer elektrolit karena tersedianya gugus sulfonat dalam strukturnya. Penelitian meliputi penerapannya untuk membran dengan penambahan molekul kecil, yaitu benzimidazol dan mengevaluasi mikrostruktur dan unjuk kerjanya. Aplikasi larutan sebagai zat pengikat dalam MEA juga akan dibahas. Hasil-hasilnya menunjukkan bahwa ketika menggunakan SPS sebagai membran sel bahan bakar, penambahan molekul kecil seperti benzimidazol akan memodifikasi mikrostrukturnya serta meningkatkan konduktifitas ioniknya, serta membuka kemungkinan untuk penerapan dengan suhu yang lebih tinggi. Sementara itu, beberapa peningkatan masih diperlukan untuk penerapan larutan SPS sebagai zat pengikat untuk pembuatan MEA.
\end{abstract}

Keywords: Polistirena tersulfonasi, Sel bahan bakar polimer elektrolit, Mikrostruktur, Benzimidazol, Konduktifitas ion

\section{INTRODUCTION}

Fuel cell is a new type of energy resource to provide free pollutant energy [1-2]. There are many types of fuel cell and one based on polymer which is called as polymer electrolyte fuel cell membrane. Amongst types 
of fuel cell, polymer electrolyte membrane fuel cell or PEMFC is the most widely applied [3-4]. In PEMFC, the fuel cell stack comprises many parts such as, catalyst which converts fuel into ion and electron, membrane which separate ion and electron, gas diffusion layer which facilitate the diffusion of fuel delivered through bipolar plate, etc.

In membrane, sulfonate group plays an important role in conducting ion. The best membranes so far is the one based on perfluorocarbon polymer [5-6]. There are a lot of available alternative for membranes [7] including sulfonated polystyrene-based membranes [8-9].

Sulfonated polystyrene is used in many applications including in vanadium redox flow batteries [10], ionomer [11-12], polymer blend [13], etc.

In our work, SPS is not only used for membrane preparation but also prepared for binding between membrane and catalyst-gas diffusion layer when preparing membrane electrode assembly or MEA.

Accordingly, it is necessary to understand the characteristics of membrane prepared with the polymer. In this work, small molecule, i.e. benzimidazole, is added to observe the effect into supramolecular structure. The effect of addition of water, which is usually occur during primary preparation prior to utilization into morphology also will be analyzed. Finally, the performance of viscous SPS as binding will also be evaluated.

The concept of preparation of membrane for PEMFC with supramolecular structure has been introduced somewhere [14]. To form the supramolecular structure, polyethylen-graft-maleic anhydride (PE-g$\mathrm{MAH}$ ) is added in the formulation. Th polymer will aligned sulfonate group in sulfonated polystyrene (SPS) through hydrogen bond formation and forming supramolecular structure. The formation of the supramolecular-structure membrane also has been proved. Therefore, it is important to understand the performance under different circumstances. In this work the variations are not only from fuel cell stacking and operation point of view, but also from membrane preparation point of view.

There some issues to be delivered in this paper. First issue will accommodate the change of molecular interaction on the addition of benzimidazole into membrane formulation. The second issue will deal the effect of water content which associated to the inclusion of sulfuric acid solution prior to fuel cell stacking. Followed by application of binding solution which is used to bridge electron produced in anode to be delivered to cathode to produce electric current. The latter will employ sulfonated polystyrene viscous fluid to replace Nafion ${ }^{\circledR}$ solution.

It is expected that the presence of benzimidazole could improve oxidative stability [15], but this work focused on change of microstructure of membrane after addition of benzimidazole. This membrane is based on SPS and, to achieve optimum ionic conductivity performance, it is built with supramolecular structure [14, 16]. Therefore, the understanding of microstructure changes on addition of benzimidazole is importance.

\section{EXPERIMENTAL}

The experiment will involve evaluation of sulfonated polystyrene in polymer electrolyte fuel cell membrane (PEMFC), i.e. for preparation of membrane and an application for binding in preparation of fuel cell stack prepared with our membrane. The detail of the experiments are as follow.

\section{Chemical}

Toluene, methanol, benzimidazole, sulfuric acid are p.a. grade and are supplied from E. Merck. All the chemicals used in this experiments are $p$. $a$ grade and no specific treatment prior to use.

\section{Viscous sulfonated polystyrene}

The viscous sulfonated polystyrene is obtained from portion of material while preparing sulfonated polystyrene with gas-solid heterogeneous sulfonation developed in our laboratorium [17].

\section{Membrane Preparation}

SPS is dissolved in toluene:methanol 9:1 and PE- $g$-MA is dissolved in toluene. Both dissolution are carried out at $40{ }^{\circ} \mathrm{C}$. The solution is mixed gently by adding PE-g-MA solution to SPS solution dropwisely at the temperature of dissolution. The resulting solution is casted into teflon cloth sheet at $40{ }^{\circ} \mathrm{C}$ to remove the solvents.

\section{Addition of Benzimidazole}

In the experiment involving benzimidazole, the chemical, in the amount of $6,25 \%, 12,5 \%$ and $25 \%$ by weight, was added to the solution of PE-g-MA dan SPS prior to casting.

\section{Measurement Instrumentation}

In this work the following measurements are involved.

\section{Differential Scanning Calorimetry}

The Differential Scanning Calorimetry (DSC) measurements were on the temperature range of ambient temperature to $250{ }^{\circ} \mathrm{C}$. The data presented is the first heating data. 


\section{Transmission Electron Microscope}

Samples for Transmission Electron Microscope (TEM) measurements were in powder form.

\section{X-Ray Diffraction}

The X-Ray Diffraction (XRD) of the sample taken from $2 \theta 10^{\circ}$ to $80^{\circ}$ at a scan rate of 0.02 per second.

\section{I-V Plot}

The I-V plot was recorded using our instrument. The hydrogen consumption were recorded.

\section{Electrochemical Impendance Spectroscopy}

The Electrochemical Impendance Spectroscopy (EIS) were recorded at voltage of $0,7 \mathrm{~V}$. The measurement was carried out to dried membrane

\section{Membrane Electrode Assembly (MEA) Prepa- ration}

Part of MEA are arranged in layers and then $t$ press treatment is appled at $20 \mathrm{kgf} / \mathrm{cm}^{2}$ to ensure a good binding on the binder in the MEA prepared.

\section{RESULT AND DISCUSSION}

In this works, we will discuss the application of SPS on membrane of PEMFC and using the SPS solution as a binding in preparation of membrane electrode assembly or MEA.

\section{Membrane}

Figure 1 is TEM image of membrane with $25 \%$ benzimidazole. The image in Figure 1 (a) indicate that there is an homogeneous part of the blend of the membrane. The figure shows the homogeneous part across the bulk of membrane. The darker portion only indicate the different of membrane during measurement.

Moreover, according to Figure 1(b), there is also part of membrane which tends to form a 'fibre' or rodlike shape. The portion may be a part of other polymer (polyethylene-graft-maleic anhydride or PE- $g$-MAH). But it is not, it most likely portion of one with rich of benzimidazole. The rod-like in dark portion of 'fibre' is a benzimidazole portion, because TEM image is a function of molecular mass. Accordingly, a small molecules which has differ molecular weight can be easily spotted. As it can be seen clearly in Figure 1(b) of inserted figure, the arrow pointed out a part of benzimidazole which distribute across the centre of the 'fibre'.

Those two observation, tell that addition of benzimidazole can modify the microstructure of the membrane. The other measurements such as XRD and thermal analysis (by measurement of DSC) should prove this finding.

Figure 2 shows the X-Ray Diffractogram of virgin SPS and membrane prepared with SPS added with benzimidazole, i.e Figure 2 shows a XRD diffractogram of SPS, and Figure 2 also shows XRD diffractograms of membrane with variation of benzimidazole content, i.e $6,25 \%, 12,5 \%$ and $25 \%$ by weight. It is clear that the addition of benzimidazole create change in their microstructure. This evidence can be seen in Figure 2, where the addition of benzimidazole lead to formation of a new hump in the XRD diffractogram at $2 \theta$ around $30^{\circ}$ (especially in addition of $12,5 \%$ benzimidazole). It is believed that this is caused by the formation of a new microstructure that formed by addition of benzimidazole.
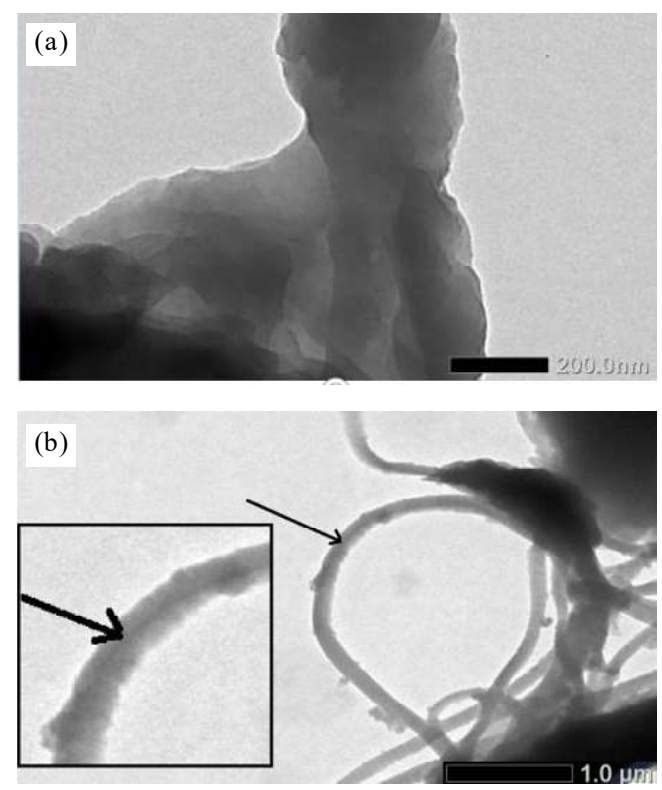

Figure 1. (a). TEM image of this fuel cell membrane with addition of benzimidazole $25 \%$ by weight; (a). homogeneous portion and (b). portion which contain benzimidazole.

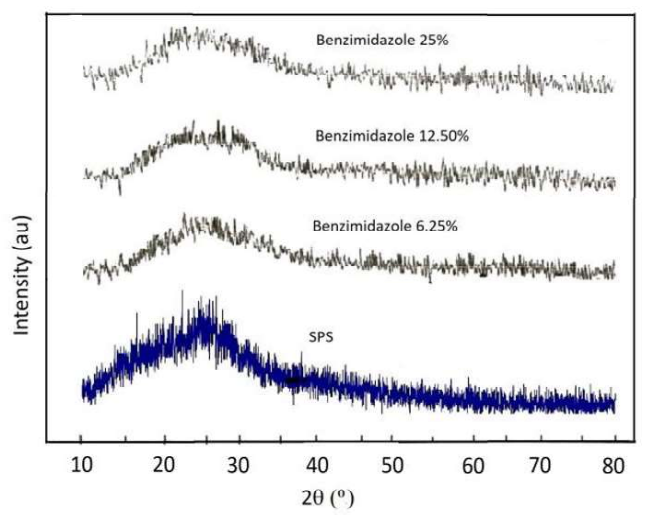

Figure 2. X-Ray Diffraction of virgin SPS and membrane prepared with various content of benzimidazole. 
This data are agree to the TEM images discussed above as well as DSC data discussed bellow.

Figure 3 is DSC thermogram of those three types of membranes. This is a first heating measurement. All the thermogram show a melting-peak-endoterm-like shape, but it is not as the baselines are not return to original baselines. Therefore, those thermal transition are incorporated to their homogeneous part of the membranes.

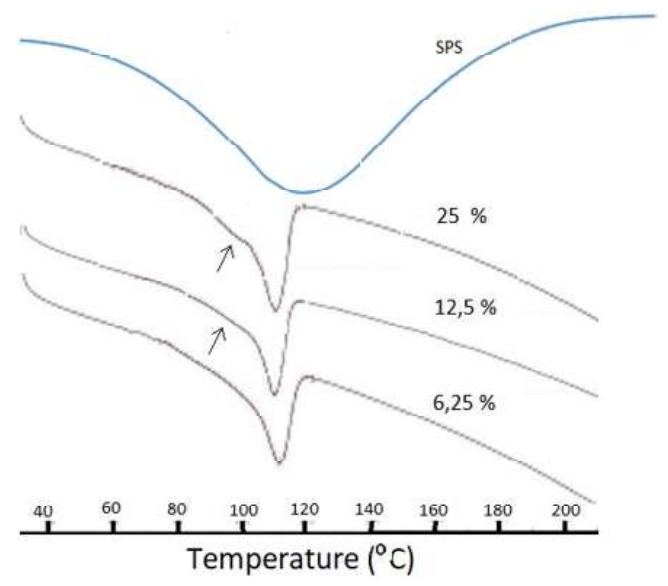

Figure 3. DSC traces of first run of the membrane with the various benzimidazole concentrations $6.25 \%, 12.5 \%$ and $25 \%$ as noted in the figure

The thermograms in Figure 3 shows a new formation of amorphous portion which occurs at lower temperature, i,e around $90{ }^{\circ} \mathrm{C}$. This indicates the new formation of amorphous parts. The formation of part increases with the increase of benzimidazole addition. This fact agree to the data of TEM and XRD. The figure 3 also present the DSC thermogram of SPS with no addition of benzimidazole. The thermogram shows different profile which may caused by the measurement carried out with different instrument which sensitivity of the instruments could probably differ from one to another.

Benzimidazole also modify conductivity properties of the membranes prepared, as can be seen in Table 1. The Table shows that ionic conductivity increase with as addition of benzimidazole increase, in general, though it seems that the highest value is membrane B. It can be explained as follow. It is known that benzimidazole could conduct ion with no or poor water content. In Nafion $^{\circledR}$, water will assist proton conduction [16], but this is not occur to this membrane as the measurement is

Table 1. Variation of ionic conductivity of membrane after addition of sulfuric acid solution invarious concentration.

\begin{tabular}{ccc}
\hline Membrane code & $\begin{array}{c}\text { Benzimidazole } \\
\text { content }\end{array}$ & $\begin{array}{c}\text { Ionic Conductivity } \times 10^{2} \\
\left(\mathrm{~S} \cdot \mathrm{cm}^{-1}\right)\end{array}$ \\
\hline $\mathrm{A}$ & 6.25 & $3.10 \times 10^{-3}$ \\
$\mathrm{~B}$ & 12.5 & $4.35 \times 10^{-3}$ \\
$\mathrm{C}$ & 25.00 & $3.95 \times 10^{-3}$ \\
\hline
\end{tabular}

carried out in dry condition. Therefore, benzimidazole portion in membrane would take over the function for proton conduction. Azole content in membrane will lowering activation of proton conductivity and therefore, the proton conduction improve [18]. Azole compound will minimize the use of water which assist proton conduction. The presence of azole compounds could takeover the role of water in proton conduction. As water content lesser than a potential energy caused by water absorption become lesser as well. Accordingly, the activation of proton conduction will also lowering.

From the above data, it is believe that this membrane could works well in less humidity than Nafion ${ }^{\circledR}$. This is an advantage of this membrane that open possibility for application in higher temperature operation due to only small water content required for having a good fuel cell performance.

At high concentration of benzimidazole added, the small decrease of ionic conductivity is observe. It could be caused by the formation of 'agglomeration' of benzimidazole itself. The 'agglomeration' could exhibit a straight flow of ion and also a possible a formation of hydrogen bond with water which retard the flow of hydrogen-water ion [19].

\section{Binding}

In this experiment, we also use sulfonated polystyrene as binding agent in preparation of MEA. The binding is very important as it will conduct proton produced during catalysis process in Anode in order the proton conduct through membrane into cathode. Therefore, type binding solution strongly affect the ionic conductivity of membrane. As shown in Figure 4, using Nafion $^{\circledR}$ solution for binding solution, at $700 \mathrm{mV}$ the current density can reach $14 \mathrm{~mA} / \mathrm{cm}^{2}$. While the one using sulfonated polystyrene solution, the cell can only reach $3 \mathrm{~mA} / \mathrm{cm}^{2}$ at $500 \mathrm{mV}$, and can not reach current density of $12 \mathrm{mV} / \mathrm{cm}^{2}$.

The both above values are significantly different. Table 2 below can be used to explain the data. In fuel cell stack using Nafion solution as binding agent in stacking, solution exhibit much higher current output. The one using SPS solution produce only $0.72 \mathrm{~A}$ while the opponent produce $4.34 \mathrm{~A}$.

Table 2. Efficieny of SPS solution for Binding agent in MEA.

\begin{tabular}{lccccc}
\hline \multirow{2}{*}{$\begin{array}{c}\text { Binding for } \\
\text { MEA }\end{array}$} & \multicolumn{2}{c}{$\begin{array}{c}\text { Hydrogen Flow } \\
\text { Rate } \\
\text { (mL/menit) }\end{array}$} & & $\begin{array}{c}\mathrm{H}_{2} \\
\text { Consumed } \\
(\%)\end{array}$ & $\begin{array}{c}\text { Current } \\
(\mathrm{A})\end{array}$ \\
\cline { 2 - 3 } & in & out & & \\
\hline Nafion ${ }^{\circledR}$ solution & 50 & 20 & & 60 & 4.34 \\
SPS solution & 50 & 45 & & 10 & 0.72 \\
\hline
\end{tabular}

However, close investigation shows that hydrogen consumption of one made with Nafion ${ }^{\circledR}$ solution is 6 times higher than that of prepared with SPS solution. It is mean that lower current output of fuel cell 



Figure 4. I-V Plot of single fuel cell stack using (a). Nafion ${ }^{\circledR}$ solution and (b). SPS solution or viscous SPS.

stack prepared with SPS solution is not caused by the solution, but other factor. And, it could be caused by the viscosity of solution itself. In fact, the solution of SPS is more viscous than Nafion solution.

\section{CONCLUSIONS}

This paper successfully demonstrated that sulfonated polystyrene or SPS not only can act as membrane but also can act as binding solution. The final performance of usage of SPS for membrane strongly affect by the addition of other component, i.e. in this experiment by using benzimidazole. Moreover, membrane based on SPS with addition of benzimidazole open possibility for application at higher temperature. As the SPS solution can also be used for binding solution, but the attention need to be drawn to its viscosity when it is applied

\section{ACKNOWLEDGEMENT}

Authors would like to acknowledge to Indonesian Institute of Sciences for funding through Program Kompetitif-LIPI.

\section{REFERENCES}

[1]. J. Cheng, G. He and F. Zhang. "A mini-review on anion exchange membranes for fuel cell applications: Stability issue and addressing strategies," International Journal of Hydrogen Energy, vol. 40, pp. 7348-7360, Jun, 2015.

[2]. V. Das, S. Padmanaban, K. Venkitusamy, R. Selvamuthukumaran, F. Blaabjerg, and P. Siano. "Recent advances and challenges of fuel cell based power system architectures and control-A review," Renewable and Sustainable Energy Reviews, vol. 73,pp. 10-18, 2017.

[3]. W. Mabrouk, L. Ogier, S. Vidal, C. Sollogoub, F. Matoussi, M. Dachraoui and J. F. Fauvarque. "Synthesis and Characterization of Polymer Blends of Sulfonated Polyethersulfone and Sulfonated Polyethersulfone Octylsulfonamide for PEMFC Applications," Fuel Cells, vol. 12, pp. 179-187, Nov, 2012.

[4]. L. Gubler and G. G. Scherer. "Trends for Fuel Cell Membrane Development," Desalination, vol. 250, pp. 1034-2037, Jan, 2010.

[5]. M. Rikukawa and K. Sanui, "Proton-Conducting Polymer Electrolyte Membranes Based on Hydrocarbon Polymers." Progress in Polymer Science, vol. 25, pp. 1463-1502, Dec, 2000.

[6]. C. H. Park, C. H. Lee, M. D. Guiver and Y. M. Lee. "Sulfonated hydrocarbon membranes for mediumtemperature and low-humidity proton exchange membrane fuel cells (PEMFCs)," Progress in Polymer Science, vol. 36, pp. 1443-1498, Nov, 2011.

[7]. E. F. Abdrashitov, D. A. Kritskaya, V. C. Bokun, A. N. Panomarev, K. S. Novikova, E. A. Sanginov and V. A. Dobrovolsky. "Synthesis and properties of stretched polytetrafluoroethylene-sulfonated polystyrene nanocomposite membranes," Solid State Ionic, vol. 286, pp. 135-140, March, 2016.

[8]. E. Y. Safronova, D. V. Golubenko, N. V. Shevlyakova, M. G. D’yakova, V. A. Tverskoi, L. Dammak, D. Grande and A. B. Yaroslavtsev. "New Cation-Exchange Membranes Based on CrossLinked Sulfonated Polystyrene and Polyethylene for Power Generation Systems," Journal of Membrane Science, vol. 515, pp. 196-203, Oct, 2016.

[9]. P. Kumar, K. Dutta, S. Das, and P. P. Kundu. "Membrane prepared by incorporation of crosslinked sulfonated polystyrene in the blend of PVdF-co-HFP/Nafion: a preliminary evaluation for application in DMFC," Applied Energy, vol. 123,pp. 66-74, 2014.

[10]. G. B. Fahs, S. D. Benson and R. B. Moore. "Blocky Sulfonation of Syndiotactic Polystyrene: A Facile Route toward Tailored Ionomer Architecture via Postpolymerization Functionalization in the Gel State," Macromolecules, Macromolecules, vol 50 (6), pp 2387-2396, March, 2017

[11]. E. B. Orler, D. J. Yontz and R. B. Moore. "Sulfonation of Syndiotactic Polystyrene for Model Semicrystalline Ionomer Investigations," Macromolecules, vol. 26, pp. 5157-5160, Sept, 1993. 
[12]. M. Jaymand. "Recent progress in the chemical modification of syndiotactic polystyrene," Polymer Chemistry, vol. 5, pp. 2663-2690, Dec, 2014

[13]. S. Hendrana, I. Rahayu, C. L. Natanael and S. Pudjiastuti. "Fuel Cell Membrane with Supramolecular Structure: ABrief Introduction and Review," in Seminar Nasional Polimer X 2015 (SNP X 2015), Surabaya, May, 2015.

[14]. H. Pan, S. Chen, Y. Zhang, M. Jin, Z. Chang and H. $\mathrm{Pu}$. "Preparation and properties of the cross-linked sulfonated polyimide containing benzimidazole as electrolyte membranes in fuel cells," Journal of MembraneScience, vol. 476, pp. 87-94, Feb, 2015
[15]. S. Hendrana, M. S. Semboor, C. L. Natanael, I. Rahayu, Mashadi and Sudirman. "Role of Preparation Method on Characteristics of Supramolecular-Structured Polymer Electrolyte Membrane Fuel Cell Based on Sulfonated Polystyrene," Jurnal Sains Materi Indonesia, vol. 18, pp. 147-154, July, 2015

[16]. K. A. Mauritz and R. B. Moore, "State Understanding of Nafion." Chemical Review, vol. 104, no. -, pp. 4535-4585, Sept, 2004.

[17]. Jiao, K., Li. X. "Water transport in polymer electrolyte membrane fuel cell", Prog. Eng Comb Sci, vol 39, pp. 221-291, Jun, 2011.

Copyright (c) 2019 Jusami | Indonesian Journal of Materials Science. This article is an open access article distributed under the terms and conditions of the Creative Commons Attribution-NonCommercial-ShareAlike 4.0 International License (CC BY-NC-SA 4.0). 